the body. The main cause for this renal insufficiency is, according to Hong? ${ }^{7}$, decrease in glomerular filtration rate which follow's the diminished renal blood flow during hypothermia.

In normal conditions the amount of nitrogen-containing compounds excreted in urine is qualitatively and quantitatively held as a criterion of protein metabolism. With reference to the protein metabolism during hibernation, analyses of urine have been performed ${ }^{8,9}$, and from the results it was deduced that the protein metabolism is greatly reduced, even more than the general metabolism. These generalized deductions based on urine analyses cannot be considered as quite valid, because the retention of catabolites of protein metabolism during hibernation is ovident.

This work was supported in part by a grant from Suomen Kulttuurirahasto.

Department of Physiological Zoology, University of Helsinki, Finland.

${ }^{1}$ Krebs, H. A. and Henseleit, K., Z. physiol. Chem., 210, 33 (1932).

${ }^{2}$ Umbreit, W. W., Burris, R. H., and Stauffer, J. F., Manometric Techniques (Minneapolis, 1959)

${ }^{3}$ Spector, W. S., Handbook of Biological Data (London, 1956).

- Musacchia, X. J., and Wilber, C. G., J. Mammal., 33, 356 (1952).

${ }^{5}$ Klar, E., Z. Exp. Med., 104, 105 (1938)

6 Suomalainen, P., Suomen Kemistilehti, A, 29, 356 (1956).

'Hong, S. K., Amer. J. Physiol., 188, 137 (1957).

' Carpenter, T. M., J. Biol. Chem., 122, 343 (1937).

'Benedict. F. G., and Lee, R. C., Carnegie Inst, Washington, Pub. 497 (1938).

\section{Response of the Testes of Purple Sea Urchins to Variations in Temperature and Light}

STUDIEs on the reproductive activity of the purple sea urchin, S. purpuratus, made during the past eight years at Pacific Grove, California, indicate the presence of an annual breeding cycle, with maximum gonadal activity occurring during the winter months. In the course of the present investigation, designed to examine the effect of latitude on the breeding activity of the sea urchin, it was observed that the sea urchin populations distributed over a $20^{\circ}$ latitudinal range have a uniform spawning period. These observations suggest that the reproductive activity of the purple sea urchin might be independent of temperature over a physiological range represented by this distribution. Therefore a photoperiodic response was considered as a possible explanation for the breeding cycles observed.

An experiment designed to test the role of light and temperature on gonadal activity of sea urchins was consequently prepared. The equipment was built and the experiment undertaken in the marine laboratory of the University of California; Los Angeles, where a 28,000gallon circulating closed sea-water system is maintained. Additional experiments were performed in the laboratory of Marineland of the Pacific, Palos Verdes, California. Two tanks were constructed; one was designed to have $14 \mathrm{~h}$ of controlled illumination, the other, $6 \mathrm{~h}$. The sea-water was maintained at $15^{\circ} \pm 0.5^{\circ} \mathrm{C}$. Twenty-five sea urchins were placed in individual plastic containers with numerous holes for proper circulation of sea water. Each animal was removed and a $0 \cdot 25$-in. hole was made in the ambitus of the interadius. The sex of the animals was determined, and the gametogenic state assessed by observation of gonadal biopsies. Males were selected for this experiment. The hole in the test was then sealed with 'Plasticine' clay and treated with penicillin.

Once the spermatogenic state has been ascertained, the twenty-five selected animals were placed in the 14-h lighted tank in their plastic containers. An abundant supply of food was maintained. When examining the sea urchins for gametogenic activity the clay plug was removed and a small biopsy of the testes taken and examined under a phase-contrast microscope. Weekly checks were made on each animal over a period of 12-15 weeks. Immediately following this period, the 25 urchins were transferred to the 6 -h lighted tank and were examined similarly.

The results obtained so far indicate that at $15^{\circ} \pm 0.5^{\circ} \mathrm{C}$ the 14-h period primarily stimulates the production of gonial cells. Occasionally, spermatocytes, spermatids, and spermatozoa were observed. However, when the day. length was reduced to $6 \mathrm{~h}$ the gonial cells, which were predominant during the long-day stimulus, were reduced in number and the spermatids, spermatocytes and spermatozoa were produced during the 6 -h artificial day.

In order to assess the significance of temperature changes alone on gonadal activity, experiments are at present being made at $10^{\circ} \mathrm{C}$. Eventually it is hoped to carry out experiments at $5^{\circ} \mathrm{C}, 20^{\circ} \mathrm{C}$, and $30^{\circ} \mathrm{C}$.

The foregoing temperatures in combination with various photoperiodic stimuli should provide an adequate means for testing gonadal activity of the sea urchin as affected by the two primary environmental variables, temperature and light.

This work was supported by a grant from the U.S. National Science Foundation, G9561, and in part by a University Research Grant and Lalor Faculty Summer Research Award.

\section{R. A. Boolootian}

Department of Zoology, University of California, Los Angeles.

\section{Demonstration of Humoral and Cellular Fixed Antibodies against Homologous Tissue Antigens}

THE question whether circulating antibodies appear during sensitization with homologous tissue antigens and whether they have an effect on the homograft reaction has often been discussed. Ever since the work of Mitchison ${ }^{1}$, there is no doubt that the mononuclear cells play an important part in the homograft reaction; however, the theory that they are carriers of sessile antibodies was not unchallenged, especially since up to this date exact methods for demonstrating cellular fixed antibodies were not known.

The aim of our investigation was first to examine serological phenomena during homograft reaction and second to detect cellular fixed antibodies against homologous tissue antigens using in vivo and in vitro methods. For donors we used healthy male albino rabbits (Weisse Wiener), for recipients healthy male rabbits of the Belgian Giant strain. For sensitization we applied tissue antigens differently prepared from the spleen and kidney of the donor. To guarantee an individual specific sensitization, the antigenic material of one donor was applied to one recipient only. To one group of rabbits (group $A$ ) we injected a mixture of spleen and kidney cells at a concen. tration of $10^{8}$ cells, to the second group $(B)$ an extract prepared according to the technique described by LejeuneLedant ${ }^{2}$ and to the third group $(C)$ an extract prepared according to the same technique but lyophilized in a concentration corresponding to $10^{8}$ cells. All antigens were applied intravenously. After 7 days, skin grafting according to Billingham and Medawar's method ${ }^{3}$ was performed in order to detect transplantation immunity. 14 days after the beginning of sensitization, a series of 5 injections of lyophilized extract was applied to each recipient at intervals of 2 days at a concentration of $2 \times 10^{7}$ cells.

The sera for the examination of serological phenomena ${ }^{4}$ were obtained before sensitization and afterwards at intervals of 7 days ( 5 blood samples altogether). Alterations in the protein content of the sera could not be demonstrated during the sensitization period. In the first two weeks the paper electrophoretic analyses of serum protein fractions showed an increase in $\alpha_{1}$-globulins in all three groups and later on a slow increase in $\gamma$-globulins which, however, was not present in group $A$. Whereas it is suggested that the increase of the $\alpha_{1}$-globulin fraction is 